\title{
PERTIMBANGAN PENGADILAN AGAMA ATAS DISPENSASI PERNIKAHAN USIA DINI AKIBAT KEHAMILAN DI LUAR NIKAH
}

\author{
Hj. Sri Ahyani \\ Sekolah Tinggi Hukum Bandung \\ E-mail:jurnal@sthb.ac.id
}

\begin{abstract}
Request dispensation marriage disconnected court as a result of promiscuity committed couples aged under predetermined Marriage Act, thus causing more widespread application for dispensation of marriage, especially because of the dispensation of wedlock majority for being pregnant out of wedlock, so inevitably must run a wedding being held accountable for what he has done, and weddings are done by the couple should get consideration from the Religious Court in the form of dispensation of marriage.
\end{abstract}

Keywords: considerations court; dispensation; marriage.

\begin{abstract}
Abstrak
Permohonan dispensasi nikah yang diputus pengadilan akibat dari pergaulan bebas yang dilakukan pasangan yang berusia di bawah yang telah ditentukan Undang-Undang Perkawinan, sehingga menyebabkan semakin maraknya permohonan dispensasi nikah, apalagi sebab dari dispensasi nikah tersebut mayoritas karena hamil di luar nikah, sehingga mau tidak mau harus menjalankan pernikahan untuk mempertanggungjawabkan apa yang telah dilakukan, dan pernikahan yang dilakukan oleh pasangan tersebut harus mendapatkan pertimbangan dari Pengadilan Agama berupa dispensasi nikah.
\end{abstract}

Kata Kunci: Pertimbangan Pengadilan, Dispensasi, Pernikahan. 


\section{A. PENDAHULUAN}

Pernikahan merupakan sunatullah yang mengikat batin antara seorang pria dan wanita yang ditandai dengan akad yang pada umumnya berasal dari keluarga yang berbeda, terutama berasal dari keluarga asalnya, yang kemudian mengikatkan dirinya menjadi satu kesatuan dalam ikatan keluarga. Keluarga sebagai institusi terkecil dalam sebuah masyarakat memegang peran yang penting bagi pembentukan generasi muda yang berkualitas. Menikah dimaksudkan untuk mencapai kebahagian dan ketentraman hidup manusia, melalui pintu pernikahan seorang laki-laki dan perempuan bisa memenuhi kebutuhan biologisnya, sedangkan secara syar'i melalui perintah Allah SWT, menikah menunjukkan betapa besar kasih sayang-Nya kepada manusia dan betapa maha luas pengetahuan Allah SWT akan kebutuhan manusia.

Manusia yang sejak lahir dibekal potensi syahwat terhadap lawan jenis membutuhkan sarana untuk menyalurkan potensi tersebut, bila potensi ini tidak tersalurkan secara terarah, maka akan menimbulkan berbagai kerawanan. Pernikahan juga merupakan suatu akad atau perikatan untuk menghalalkan hubungan kelamin antara laki-laki dan perempuan dalam rangka mewujudkan kebahagian hidup keluarga yang diliputi rasa ketentraman serta kasih sayang dengan cara yang diridlai Allah SWT. ${ }^{1}$

Setiap orang yang menjalankan pernikahan pasti tidak terlepas dari kehidupan berkeluarga dan menempuh kehidupan dalam pernikahan adalah harapan dan niat yang wajar dan sehat dari setiap anak muda dan remaja dalam masa pertumbuhannya. Pengalaman dalam kehidupan menunjukkan, bahwa membangun keluarga itu mudah, namun memelihara dan membina keluarga hingga mencapai taraf kebahagiaan dan kesejahteraan yang selalu didambakan oleh setiap pasangan suami-istri sangat sulit. Oleh karena itu, keluarga yang dapat mencapai kebahagiaan dan kesejahteraan ini yang disebut dengan keluarga sakinah, mawadah, dan warahmah. Untuk mewujudkan pernikahan yang sesuai dengan yang inginkan kedewasaan dalam hal fisik dan rohani dalam pernikahan merupakan dasar untuk mencapai tujuan dan cita-cita dari pernikahan, walaupun demikian banyak dari masyarakat yang kurang menyadari hal itu disebabkan oleh pengaruh lingkungan, pengaruh pendidikan, dan perkembangan sosial yang tidak memadai.

Untuk menjembatani terwujudnya pernikahan yang sesuai dengan tujuan dari pernikahan, maka Undang-Undang Nomor 1 Tahun 1974 tentang Perkawinan telah menentukan dan menetapkan dasardasar yang harus dilaksanakan dalam perkawinan. Salah satu di antaranya adalah Pasal 7 ayat (1) yang menyatakan, bahwa: "Perkawinan hanya diizinkan jika pihak pria sudah mencapai umur 19 (sembilan belas) tahun dan pihak wanita mencapai umur 16 (enam belas) tahun", dan dalam ayat selanjutnya menyatakan bahwa bila terdapat penyimpangan pada

1 Direktoral Jenderal Pembinaan Kelembagaan Agama Islam, Ilmu Fiqihh Jilid II, Departemen Agama, Jakarta, 1985, hlm. 49. 
Pasal 7 ayat (1) dapat meminta dispensasi pada pengadilan atau pejabat lain yang ditunjuk oleh kedua belah pihak baik dari pihak pria atau pihak wanita.

Batas umur di Indonsia relatif rendah dan dalam pelaksanaannya sering tidak dipatuhi sepenuhnya, padahal diharapkan agar orang melangsungkan pernikahan di atas batas umur terendah, namun dalam praktiknya pernikahan justru terjadi diusia kurang dari usia yang telah ditetapkan dalam Undang-Undang Nomor 1 Tahun 1974, sehingga untuk hal tersebut Pasal 6 ayat (2) telah memberikan suatu pengaturannya dengan menyatakan sebagai berikut: "Untuk melangsungkan perkawinan seorang yang belum mencapai umur 21 (dua puluh satu) tahun harus mendapat izin kedua orang tua".

Di dalam Al-qur’an memang tidak secara sepesifik membahas tentang usia perkawinan hanya menetapkan dengan tanda-tanda dan isyarat, sehingga diserahkan kepada ranah fiqh dan kepada kaum muslimin untuk menentukan batas umur yang sebaiknya yang sesuai dengan syarat dan tanda-tanda yang telah ditentukan, dan disesuaikan dengan tempat di mana hukum itu akan diundangkan. ${ }^{2}$ Demikian juga dalam hukum adat tidak ada ketentuan batas umur untuk melakukan pernikahan, namun biasanya kedewasaan seseorang dalam hukum adat diukur dengan tanda-tanda bagian tubuh, apabila anak wanita sudah haid (datang bulan), buah dada sudah menonjol berarti sudah dewasa. Bagi laki-laki ukurannya dilihat dari perubahan suara, postur tubuh dan sudah mengeluarkan air mani atau sudah mempunyai nafsu seks. ${ }^{3}$

Bagi seorang pemuda, usia untuk memasuki gerbang perkawinan dan kehidupan berumah tangga padaumumnya dititik beratkan pada kematengan asmani dan kedewasaan pikiran orang serta kesanggupannya untuk memikul tanggung jawab sebagai suami dalam rumah tangganya, itu merupakan patokan umur bagi para pemuda kecuali ada faktor lain yang menyebabkan harus dilaksanakannya pernikahan lebih cepat, bagi seorang gadis usia perkawinan itu karena berkaitan dengan kehamilan dan kemungkinan besar setelah melangsungkan perkawinan akan terjadi kehamilan. Oleh karena itu, perlu memperhitungkan kematangan jasmani dan ruhaninya yang memungkinkan dapat menjalankan tugas sebagai seorang istri dan sekaligus sebagai seorang ibu yang sebaik-baiknya, jika diambil patokan yang paling bagus bagi seorang gadis untuk menjalankan perkawinan yang sesuai dengan keadaan di Indonesia batas terendah bagi bagi seorang gadis adalah 18 tahun karena ada umur 18 seorang wanita sudah mencapai tinggkat kematangan biologis seorang wanita. ${ }^{4}$ Akan tetapi terkadang anak belum mencapai umur 18 tahun sudah melangsungkan pernikahan karena alasan-alasan tertentu, untuk itu bagi yang masih di bawah umur untuk melangsungkan pernikahan, maka

\footnotetext{
Kamal Muchtar, Asas-asas Hukum Islam tentang Perkawinan, Bulan Bintang, Jakarta, 1974, hlm. 44. Hilman Hadikusumah, Hukum Perkawinan Indonesia Menurut Perundangan, Hukum Adat dan Hukum Agama, Mandar Maju, Bandung, 1990, hlm. 53.

4 Sutan Marajo Nasaruddin Latif, Problematika Seputar Keluarga dan Rumah Tangga, Pustaka Hiddayah, Bandung, 2001, hlm. 23.
} 
harus mendapat dispensasi nikah dari pengadilan agama setempat.

\section{B. PEMBAHASAN}

\section{Pengertian, Tujuan, dan Syarat- syarat Pernikahan}

Perkawinan ialah ikatan lahir batin antara seorang pria dengan seorang wanita sebagai suami istri dengan tujuan membentuk keluarga (rumah tangga) yang bahagia dan kekal berdasarkan Ketuhanan Yang Maha Esa. Rumusan perkawinan tersebut merupakan rumusan yang tercantum dalam Pasal 1 angka (1) Undang-Undang Nomor 1 Tahun 1974 yang dalam penjelasannya disebutkan sebagai berikut:

"Sebagai negara yang berdasarkan Pancasila, di mana Sila yang pertamanya ialah Ketuhanan Yang Maha Esa, maka perkawinan mempunyai hubungan yang erat sekali dengan agama/kerohanian, sehingga perkawinan bukan saja mempunyai unsur lahir/jasmani, tetapi unsur batin/rohani juga mempunyai peranan yang penting .....

Rumusan perkawinan menurut Undang-Undang Nomor 1 Tahun 1974 di atas, pada dasarnya mengandung inti dan tujuan yang sama dengan rumusanrumusan perkawinan dari para ahli/ sarjana hukum, misalnya Paul Scholten ${ }^{5}$ mengemukakan sebagai berikut:
"Perkawinan adalah suatu hubungan hukum antara seorang pria dengan seorang wanita untuk hidup bersama dengan kekal yang diakui oleh negara".

Sarjana Hukum Indonesia, seperti Subekti dan Wirjono Prodjodikoro, mengemukakan juga mengenai pengertian perkawinan. Subekti mengemukakan bahwa perkawinan ialah pertalian yang sah antara seorang laki-laki dengan seorang perempuan untuk waktu yang lama, ${ }^{6}$ sedangkan Wirjono Prodjodikoro mengemukkan bahwa perkawinan ialah hidup bersama dari seorang laki-laki dan seorang perempuan yang memenuhi syarat-syarat tertentu. ${ }^{7}$

Berdasarkan rumusan perkawinan tersebut, bahwa perkawinan itu tidak hanya merupakan ikatan lahir saja atau ikatan batin saja, akan tetapi ikatan keduaduanya. Ikatan lahir dalam perkawinan merupakan hubungan hukum antara seorang pria dengan seorang wanita untuk hidup bersama sebagai suami istri. Ikatan lahir ini merupakan hubungan formil yang sifatnya nyata, baik bagi yang mengikatkan dirinya maupun bagi orang lain atau masyarakat. ${ }^{8}$ Ikatan lahir ini terjadi dengan adanya upacara perkawinan yakni upacara akad nikah bagi yang beragama Islam.

Ikatan batin dalam perkawinan merupakan pertalian jiwa yang terjalin karena adanya kemauan yang sama dan ikhlas antara seorang pria dengan seorang

\footnotetext{
$5 \quad$ Paul Scholten dalam Djaya S. Meliala, Masalah Perkawinan Antar Agama dan Kepercayaan di Indonesia dalam Perspektif Hukum, Vrama Vidya Dharma, Bandung, 2006, hlm. 7.

Ibid.

Ibid.

K. Wantjik Saleh, Hukum Perkawinan Indonesia, Ghalia Indonesia, Jakarta, 1976, hlm. 14-15.
} 
wanita untuk hidup bersama sebagai suami istri. Dalam tahap permulaan, ikatan batin ini diawali dan ditandai dengan adanya persetujuan dari calon mempelai untuk melangsungkan perkawinan. Selanjutnya dalam hidup bersama ikatan batin ini tercermin dari adanya kerukunan suami istri yang bersangkutan. Terjalinnya ikatan lahir dan batin merupakan dasar utama dalam membentuk dan membina keluarga yang bahagia dan kekal.

Walaupun ada beberapa perbedaan pendapat dari rumusan/definisi perkawinan ini, dapat dikemukakan ada satu unsur yang merupakan kesamaan, yakni bahwa perkawinan merupakan suatu perjanjian, yaitu perjanjian antara seorang laki-laki dan seorang wanita. Pengertian perjanjian di sini bukan dalam arti seperti yang dimuat dalam Buku III KUH Perdata, tetapi perjanjian dalam arti perjanjian kekeluargaan. ${ }^{9}$

Menurut Wirjono Prodjodikoro, perbedaan antara perjanjian perkawinan dan perjanjian lainnya (seperti perjanjian jual beli dan lain-lain) adalah dalam hal perjanjian biasa para pihak bebas menentukan isi perjanjian, sepanjang tidak bertentangan dengan isi perjanjian, tidak bertentangan dengan undangundang, kesusilaan dan ketertiban umum, sedangkan dalam perjanjian perkawinan, isi perjanjian telah ditentukan oleh undang-undang/hukum.

Menyimak rumusan perkawinan menurut Undang-Undang Nomor 1 Tahun 1974, tercantum juga tujuan perkawinan, yaitu untuk membentuk keluarga (rumah tangga) yang bahagia dan kekal. Ini berarti bahwa perkawinan di langsungkan bukan untuk sementara atau untuk jangka waktu tertentu yang direncanakan, akan tetapi untuk seumur hidup atau selama-lamanya dan tidak boleh diputus begitu saja, sebab tidak diperkenankan perkawinan yang hanya dilangsungkan untuk sementara waktu saja, seperti kawin kontrak. Pemutusan perkawinan dengan perceraian hanya diperbolehkan dalam keadaan yang sangat terpaksa.

Selanjutnya dalam rumusan perkawinan menurut Undang-Undang Nomor 1 Tahun 1974 dinyatakan dengan tegas bahwa pembentukan keluarga (rumah tangga) yang bahagia dan kekal itu berdasarkan Ketuhanan Yang Maha Esa. Ini berarti, bahwa perkawinan harus didasarkan pada agama dan kepercayaan masing-masing. Oleh karena itu, maka dalam Pasal 2 ayat (1) UndangUndang Nomor 1 Tahun 1974 berikut penjelasannya menyatakan sebagai berikut:

"Perkawinan sah, apabila dilakukan menurut hukum masing-masing agamanya dan kepercayaannya itu". Dalam perjelasannya dinyatakan, bahwa dengan rumuan Pasal 2 ayat (1) ini, tidak ada perkawinan di luar hukum masing-masing agamanya dan kepercayaannya itu sesuai dengan Undang-Undang Dasar Negara Republik Indonesia Tahun 1945".

Sebagaimana telah dikemukakan, bahwa yang menjadi tujuan perkawinan menurut Undang-Undang Nomor 1 Tahun 1974 adalah membentuk keluarga

$9 \quad$ Djaya S. Meliala, Op.Cit., hlm. 7. 
(rumah tangga) yang bahagian dan kekal berdasarkan Ketuhanan Yang Maha Esa. Dari pengertian ini berarti pernikahan mengandung aspek akibat hukum yaitu saling mendapat hak dan kewajiban, serta bertujuan mengadakan pergaulan yang dilandasi tolong menolong. Oleh karena perkawinan termasuk dalam pelaksanaan syari`at agama, maka didalamnya terkandung tujuan dan maksud. ${ }^{10}$ Adapun tujuan dari pernikahan menurut Islam adalah sebagai berikut: ${ }^{11}$

a. Untuk memenuhi tuntutan naluri manusia yang asasi.

Perkawinan merupakan fitra manusia yang dilakukan dengan cara-cara yang telah diatur diundang-udangan perkawinan dan beberapa hukum agama, sehingga suatu hubungn menjadi sah dan halal, bukan dengan cara yang diharamkan yang telah menyimpang dari ajaran agama.

b. Untuk membentengi akhlak yang luhur.

Sasaran utama dari syariat pernikahan adalah untuk membentengi martabat manusia dari perbuatan kotor dan keji yang telah menurunkan martabat manusia yang luhur. Islam memandang perkawinan dan pembentukan keluarga sebagai sarana efektif untuk memelihara pemuda dan pemudi dari kerusakan serta melindungi masyarakat dari kekacauan, Rasulullah Saw bersabda:

"Wahai para pemuda barang siapa diantara kalian berkemampuan untuk nikah, maka nikahlah karena nikah itu lebih menundukkan pandangan dan lebih membentengi farji (kemaluan). Dan barang siapa yang tidak mampu, maka hendaklah ia berpuasa karena puasa itu dapat membentengi dirinya".

c. Untuk menegakkan rumah tangga yang Islami

Dalam keluarga Islam membenarkan adanya perceraian, jika suami tidak sanggup lagi menegakkan batas-batas Allah SWT, sebagaiman firman Allah SWT: ${ }^{12}$

"Talak (yang dapat dirujuki) dua kali. Setelah itu boleh rujuk lagi dengan cara yang ma'ruf atau menceraikan dengan cara yang baik. tidak halal bagi kamu mengambil kembali sesuatu dari yang telah kamu berikan kepada mereka, kecuali kalau keduanya khawatir tidak akan dapat menjalankan hukumhukum Allah SWT. jika kamu khawatir bahwa keduanya (suami isteri) tidak dapat menjalankan hukum-hukum Allah SWT, maka tidak ada dosa atas keduanya tentang bayaran yang diberikan oleh isteri untuk menebus dirinya. Itulah hukum-hukum Allah SWT, maka janganlah kamu melanggarnya. Barangsiapa yang melanggar hukum-hukum Allah SWT mereka Itulah orangorang yang zalim".

Pasal 1 undang-undang perkawinan menyatakan, bahwa perkawinan ialah ikatan lahir batin antara seorang pria dengan seorang wanita sebagai suami istri dengan tujuan membentuk keluarga (rumah tangga) yang bahagia dan kekal berdasarkan ketuhanan Yang Maha

\footnotetext{
10 Abdurrahman, Kompilasi Hukum Islam di Indonesia, Akademika Pressindo, Jakarta, 1995, hlm. 114.

11 Ibid.

12 Q.S. Al-Baqarah ayat 229.
} 
Esa, tujuan perkawinan dilihat sebagai perintah Allah SWT untuk memperoleh keturunan yang sah dalam masyarakat dengan mendirikan rumah yang damai dan teratur dalam rumusan Pasal 2 dan 3 KHI dikemukakan sebagai berikut:

"Perkawinan menurut hukum Islam adalah pernikahan, yaitu akad yang sangat kuat atau mitsaaqon gholiidhan untuk mentaati perintah Allah SWT dan melaksanakannya merupakan ibadah", dan perkawinan bertujuan untuk mewujudkan kehidupan rumah tangga yang sakinah, mawaddah, dan rahmah".

Menurut Imam Ghazali dalam kitabnya Ihya' 'Ulum ad-Din dapat disimpulkan sebagai berikut: ${ }^{13}$

a. Memperoleh keturunan yang sah.

b. Mencegah zina.

c. Menyenangkan dan menentramkan jiwa.

d. Mengatur rumah tangga.

e. Usaha untuk mencari rizki yang halal.

f. Menumbuhkan dan memperbesar rasa tanggung jawab.

Untuk lebih menjamin tercapainya tujuan perkawinan tersebut, maka orang yang akan melangsungkan perkawinan menurut Undang-Undang Nomor 1 Tahun 1974 harus memenuhi syarat-syarat tertentu dan melalui prosedur tertentu pula. Perkawinan adalah suatu perbuatan hukum yang mempunyai akibat-akibat hukum. Sah atau tidaknya suatu perbuatan hukum ditentukan oleh hukum positif di bidang perkawinan, yaitu Undang-Undang Nomor 1 Tahun 1974. Dengan demikian, sah tidaknya suatu perkawinan ditentukan oleh ketentuan-ketentuan yang ada dalam undang-undang tersebut sebagaimana yang diatur dalam Pasal 2.

Atas dasar ketentuan Pasal 2 ayat (1) beserta penjelasannya, Hazairin ${ }^{14}$ mengatakan, sebagai berikut:

"Hukum agama dan kepercayaan yang dimaksud bukanlah hanya hukum yang dijumpai dalam kitab-kitab suci atau dalam keyakinan-keyakinan yang terbentuk dalam gereja-gereja kristen atau dalam kesatuan-kesatuan masyarakat (seperti di Bali) yang berkepercayaan Ketuhanan Yang Maha Esa itu, tetapi juga semua ketentuan-ketentuan perundangundanan (sekedar yang masih berlaku bagi setiap golongan agama dan kepercayaan masing-masing itu) baik yang telah mendahului Undang-Undang Nomor 1 Tahun 1974 (lihat Pasal 66) maupun yang akan ditetapkan lagi kelak, misalnya bagi pelaksanaan Undang-Undang Nomor 1 Tahun 1974, yaitu Pasal 11 ayat (2), 12, 16 ayat (2), 39 ayat (3), 40 ayat (2), 43 ayat (2) dan Pasal 67. Dengan demikian, dari rumusan Pasal 2 ayat (1) beserta penjelasannya itu, maka suatu perkawinan mutlak harus dilakukan menurut hukum agama dan kepercayaannya itu".

\footnotetext{
13 Imam Abu Hamid Muhammad Ibn Muhammad al-Ghazali, Ihya 'Ulum ad-Din, Jilid 2, Dar al-Fikr, Beirut Libanon, 1989, hlm. 27-40.

14 Hazairin dalam Ridwan Syahrani, Seluk Beluk dan Asas-asas Hukum Perdata, Alumni, Bandung, 2002, hlm. 96.
} 
Ketentuan Pasal 2 ayat (1) UndangUndang Nomor 1 Tahun 1974, bahwa Undang-Undang ini menggantungkan sahnya suatu perkawinan kepada hukum agama dan kepercayaan masing-masing pemeluknya, hal ini berarti bahwa syaratsyarat perkawinan itu sendiri mestinya jugaharus didasarkan kepadasyarat-syarat perkawinan sebagai yang diatur menurut hukum agama dan kepercayaannya itu. Walaupun demikian, Undang-Undang Nomor 1 Tahun 1974 mengatur syaratsyarat sahnya suatu perkawinan. Hal ini adalah wajar bila dihubungkan dengan tujuan unifikasi hukum perkawinan itu sendiri, yaitu memperlengkapi apa yang tidak diatur hukumnya dalam hukum agama dan kepercayaanya itu.

Syarat-syarat sahnya perkawinan yang diatur dalam Undang-Undang Nomor 1 Tahun 1974 meliputi syarat-syarat materiil maupun formil. Syarat-syarat materiil, yaitu syarat-syarat yang mengenai diri pribadi calon mempelai, sedangkan syarat formil menyangkut formalitas-formalitas atau tata cara yang harus dipenuhi sebelum dan pada saat dilangsungkannya perkawinan. Syarat materiil itu sendiri ada yang berlaku untuk semua perkawinan (umum) dan yang berlaku hanya untuk perkawinan tertentu saja.

Syarat-syarat sahnya perkawinan yang materiil umum dibagi ke dalam 2 (dua) bagian, yaitu: ${ }^{15}$

a. Syarat-syarat materiil yang berlaku umum:

Syarat-syarat yang termasuk ke dalam kelompok ini diatur di dalam pasal dan mengenai hal sebagai berikut:

1) Harus ada persetujuan dari kedua calon mempelai.

2) Usia calon mempelai pria sudah mencapai 19 tahun dan wanita sudah mencapai 16 tahun.

3) Tidak terikat tali perkawinan dengan orang lain (kecuali dalam hal diijinkan sebagaimana diatur dalam Pasal 3 ayat (2) dan Pasal 4 Undang-Undang Nomor 1 Tahun 1974.

4) Waktu tunggu bagi seorang wanita yang putus perkawinannya, yaitu:

a) 130 hari, bila perkawinan putus karena kematian.

b) 3 kali suci atau minimal 90 hari bila putus karena perceraian dan ia masih berdatang bulan.

c) 90 hari, bila putus karena perceraian, tetapi tidak berdatangan bulan.

d) Waktu tunggu sampai melahirkan, bila si janda dalam keadaan hamil.

5) Tidak ada waktu tunggu, bila belum pernah terjadi hubungan kelamin.

6) Penghitungan waktu tunggu dihitung sejak jatuhnya putusan pengadilan yang mempunyai kekuatan hukum yang tetap bagi suatu perceraian dan sejak hari kematian bila perkawinan putus karena kematian.

Tidak dipenuhinya syarat-syarat tersebut menimbulkan ketidak-

15 Asmin, Status Perkawinan Antar Agama Ditinjau dari Undang-Undang No. 1/1974, Dian Rakyat, Jakarta, 1986, hlm. 20-25. 
wenangan untuk melangsungkan perkawinan dan berakibat batalnya suatu perkawinan.

b. Syarat materiil yang berlaku khusus.

Syarat ini hanya berlaku untuk perkawinan tertentu saja dan meliputi hal-hal sebagai berikut:

1) Tidak melanggar perkawinan sebagaimana diatur dalam Pasal 8, 9 dan Pasal 10 Undang-Undang Nomor 1 Tahun 1974, yaitu mengenai larangan perkawinan antara dua orang yang:

a) Berhubungan darah dalam garis keturunan lurus ke bawah atau pun ke atas.

b) Berhubungan darah dan garis keturunan ke samping.

c) Berhubungan semenda.

d) Berhubungan susuan.

e) Berhubungan saudara dengan istri atau sebagai bibi atau kemenakan dari istri dalam hal seorang suami istri lebih dari seorang.

f) Mempunyai hubungan yang oleh agamanya atau peraturan lain yang berlaku dilarang kawin.

g) Masih terikat tali perkawinan dengan orang lain, kecuali dalam hal tersebut pada Pasal 3 ayat (2) dan Pasal 4.

h) Telah bercerai untuk kedua kalinya, sepanjang hukum masing-masing agamanya dan kepercayaannya tidak menentukan lain.

2) Ijin orang tua bagi mereka yang belum mencapai usia 21 tahun.
Syarat-syarat formil ini meliputi hal-hal sebagai berikut:

a) Pemberitahuan kehendaknya akan melangsungkan perkawinan kepada pegawai pencatat perkawinan.

b) Pengumuman oleh pegawai pencatat perkawinan.

c) Pelaksanaan perkawinan menurut hukum agamanya dan kepercayaanya masingmasing.

d) Pencatatan perkawinan oleh pegawai pencatat perkawinan.

Selain syarat-syarat di atas, masih ada hal-hal yang harus diperhatikan untuk dapat melangsungkan suatu perkawinan. Hal dimaksud adalah mengenai larangan perkawinan sebagaimana dimaksud dalam Pasal 8 Undang-Undang Nomor 1 Tahun 1974.

\section{Pertimbangan Hakim Pengadilan Agama dalam Pemberian Dispensasi Pernikahan Akibat Hamil di Luar Nikah}

Seseorang yang hendak menikah namun usianya belum mencukupi menurut Undang-Undang Nomor 1 Tahun 1974 harus mendapatkan izin dari Pengadilan. Khusus yang beragama Islam, pengajuan permohonan dispensasi kawin di Pengadilan Agama oleh orang tua sebagai pemohon dengan ketentuan sebagai berikut:

a. Mekanisme Pengajuan Perkara

Permohonan Dispensasi Kawin di Pengadilan Agama.

Mekanisme pengajuan perkara permohonan sama dengan mekanisme pengajuan perkara gugatan. Adapun 
mekanisme pengajuan perkara permohonan di Pengadilan Agama adalah sebagai berikut:

1) Prameja

Sebelum pemohon mengajukan permohonannya, pemohon ke prameja terlebih dahulu untuk memperoleh penjelasan tentang bagaimana cara berperkara, cara membuat surat permohonan, dan di prameja pemohon dapat minta tolong untuk dibuatkan surat permohonan.

2) Meja I

Surat permohonan yang telah dibuat dan ditandatangani diajukan pada sub Kepaniteraan Permohonan, pemohon menghadap pada meja pertama yang akan menaksir besarnya panjar biaya perkara dan menuliskanya pada Surat Kuasa Untuk Membayar (SKUM). Besarnya panjar biaya perkara diperkirakan harus telah mencukupi untuk menyelesaikan perkara tersebut, yang berdasarkan Pasal $193 \mathrm{RBg} /$ Pasal 182 ayat (1) HIR/Pasal 90 ayat (1) UUPA, meliputi:

a) Biaya kepaniteraan dan biaya materai.

b) Biaya pemeriksaan, saksi ahli, juru bahasa dan biaya sumpah.

c) Biaya pemeriksaan setempat dan perbuatan Hakim yang lain.

d) Biaya pemanggilan, pemberitahuan dan lain-lain atas perintah Pengadilan yang berkenaan dengan perkara itu. Bagi yang tidak mampu dapat diijinkan berperkara secara prodeo (cuma-cuma). Ketidakmampuan tersebut dibuktikan dengan melampirkan surat keterangan dari Lurah/Kepala Desa setempat yang dilegalisir oleh Camat. Bagi yang tidak mampu maka panjar biaya perkara ditaksir Rp. 0,00 dan ditulis dalam SKUM.

3) Kasir

Pemohon kemudian menghadap kepada kasir dengan menyerahkan surat permohonan dan SKUM. Kasir kemudian:

a) Menerima uang tersebut dan mencatat dalam jurnal biaya perkara.

b) Menandatangani dan memberi nomor perkara serta tanda lunas pada SKUM.

c) Mengembalikan surat permohonan dan SKUM kepada Pemohon.

4) Meja II

Pemohon kemudian menghadap pada Meja II dengan menyerahkan surat permohonan dan SKUM yang telah dibayar. Kemudian Meja II:

a) Memberi nomor pada surat permohonan sesuai dengan nomor yang diberikan oleh Kasir. Sebagai tanda telah terdaftar maka petugas Meja II membubuhkan paraf.

b) Menyerahkan satu lembar surat permohonan yang telah terdaftar bersama satu helai SKUM kepada pemohon. 
b. Proses Penyelesaian Perkara

Permohonan Dispensasi Kawin di Pengadilan Agama

Ketua Majelis Hakim setelah menerima berkas perkara, bersama-sama hakim anggotanya mempelajari berkas perkara. Kemudian menetapkan hari dan tanggal serta jam kapan perkara itu disidangkan serta memerintahkan agar para pihak dipanggil untuk datang menghadap pada hari, tanggal, dan jam yang telah ditentukan.

Kepada para pihak diberitahukan pula, bahwa dapat mempersiapkan bukti-bukti yang diajukan dalam persidangan. Namun, biasanya bukti-bukti sudah dititipkan kepada panitera sebelum persidangan. Setelah persidangan dibuka dan dinyatakan terbuka untuk umum oleh Ketua Majelis, maka para pihak berperkara dipanggil ke ruang persidangan. Kemudian Ketua Majelis berusaha menasehati pemohon, anak pemohon dan calon anak pemohon dengan memberikan penjelasan tentang sebab akibatnya apabila pernikahan dilakukan belum cukup umur dan agar menunda pernikahannya. Bila tidak berhasil dengan nasehat-nasehatnya, kemudian Ketua Majelis membacakan surat permohonan pemohon yang telah didaftarkan di Kepaniteraan Pengadilan Agama.

Selanjutnya Ketua Majelis memulai pemeriksaan dengan pertanyaanpertanyaan yang diajukan kepada pemohon, anak pemohon dan calon anak pemohon secara bergantian. Kemudian Ketua Majelis melanjutkan pemeriksaan bukti surat, dan pemohon menyerahkan bukti surat:
1) Foto copy surat kelahiran atas nama anak pemohon yang dikeluarkan oleh Kepala Desa/ Kelurahan, oleh Ketua Majelis diberi tanda P.1.

2) Surat pemberitahuan penolakan melangsungkan pernikahan Model N-9 yang dikeluarkan oleh Kantor Urusan Agama.

Selanjutnya Ketua Majelis menyatakan sidang diskors untuk musyawarah. Pemohon, anak pemohon dan calon anak pemohon diperintahkan ke luar dari ruang persidangan. Setelah musyawarah selesai, skors dicabut dan pemohon dipanggil kembali masuk ke ruang persidangan, kemudian dibacakan penetapan yang amarnya sebagai berikut :

\section{MENGADILI}

1) Mengabulkan permohonan pemohon.

2) Menetapkan memberi Dispensasi kepada pemohon untuk menikahkan anaknya bernama $\mathrm{xx}$ dengan xxx.

3) Membebankan biaya perkara sebesar Rp. ... (...) kepada pemohon.

Setelah membacakan penetapannya, Ketua Majelis menyatakan sidang ditutup. Jika pemohon tidak puas dengan penetapan Hakim, pemohon bisa langsung kasasi, bukan banding.

Berdasarkan uraian di atas, dalam memeriksa suatu perkara, hakim bertugas untuk mengkonstatir, mengkualifisir dan kemudian mengkonstituir. Mengkonstatir artinya hakim harus menilai apakah peristiwa atau faktafakta yang dikemukakan oleh para 
pihak itu adalah benar-benar terjadi. Hal ini hanya dapat dilakukan melalui pembuktian. Membuktikannya artinya mempertimbangkan sacara logis kebenaran suatu fakta atau peristiwa berdasarkan alat-alat bukti yang sah dan menurut hukum pembuktian yang berlaku

Dalam pembuktian itu, maka para pihak memberi dasar-dasar yang cukup kepada hakim yang memeriksa perkara yang bersangkutan guna memberi kepastian tentang kebenaran peristiwa yang diajukan. Fakta ialah keadaan, peristiwa atau perbuatan yang terjadi (dilakukan) dalam dimensi ruang dan waktu. Suatu fakta dapat dikatakan terbukti apabila telah diketahui kapan, dimana, dan bagaimana terjadinya. Misalnya masalah dispensasi kawin, fakta yang perlu dicari kebenarannya adalah apakah seseorang tersebut benar-benar ingin melakukan pernikahan di bawah umur dengan alasan dan bukti-bukti yang dicantumkan dalam berkas permohonan dispensasi yang diajukan orang tuanya ke Pengadilan Agama.

Konkritnya dalam memberi penetapan, hakim tidak boleh keluar dari koridor hukum yang mengatur tentang persoalan yang diperkarakan. Penetapan hakim akan menjadi kepastian hukum dan mempunyai kekuatan mengikat untuk dijalankannya, karena penetapan hakim adalah pernyataan hakim yang dituangkan dalam bentuk tertulis dan diucapkan oleh hakim dalam sidang terbuka untuk umum, sebagai hasil dari pemeriksaan perkara.

Ketika ingin menjatuhkan penetapan, hakim memiliki pertimbanganpertimbangan yang diklasifikasikan menjadi 2 (dua), yaitu: a. Pertimbangan Hukum

Pertimbangan hukum di sini berarti ketika hakim menjatuhkan penetapannya harus sesuai dengan dalil-dalil dan bukti-bukti hukum yang diajukan. Bukti-bukti yang biasa disyaratkan menurut undang-undang adalah:

1) Bukti surat

a) Foto copy Surat Kelahiran atas nama anak Pemohon yang dikelurkan oleh Kepala Desa/ Kelurahan.

b) Surat Pemberitahuan Penolakan Melangsungkan Pernikahan (Model N-9) yang di keluarkan oleh Kantor Urusan Agama.

2) Bukti saksi

Adapun bukti saksi yang biasa dihadirkan oleh hakim dalam persidangan adalah dua orang. Namun karena dalam perkara ini perkara permohonan dispensasi kawin, maka saksi hanya kalau diperlukan saja.

Dalam pertimbangannya, hakim juga berdasarkan hukum Islam yakni menolak bahaya didahulukan atas mendatangkan kebaikan dan Kemadharatan harus dihilangkan yang pada dasarnya setiap insan tidak diizinkan mengadakan suatu kemadharatan, baik berat maupun ringan terhadap dirinya atau terhadap orang lain. Pada prinsipnya kemadharatan harus dihilangkan, tetapi dalam menghilangkan kemadharatan itu tidak boleh sampai menimbulkan kemadharatan lain baik ringan apalagi lebih berat. Namun, bila kemadharatan itu tidak 
dapat dihilangkan kecuali dengan menimbulkan kemadharatan yang lain maka haruslah memilih kemadharatan yang relatif lebih ringan dari yang telah terjadi. Menurut persepsi hakim, madharatnya adalah ditakutkan bila tidak dinikahkan akan menambah dosa dan terjadi perkawinan di bawah tangan yang akan mengacaukan proses-proses hukumyang akan terjadi berikutnya atau mengacaukan hakhak hukum anak yang dilahirkannya menurut undang-undang.

b. Pertimbangan Keadilan Masyarakat

Seringkali pernikahan dianggap sebagai solusi alternatif bagi penyelesaian masalah sosial yang akan terjadi, yaitu menikahkan anak yang sudah hamil terlebih dahulu untuk menutup malu. Hasil observasi penulis di Pengadilan Agama, hakim selalu mengabulkan permohonan dispensasi kawin karena hubungan di luar nikah, dengan pertimbangan perempuan yang hamil tanpa suami akan dihina dan dikucilkan oleh masyarakat. Ini bisa mengakibatkan perempuan tersebut tidak mau bergaul dan mementingkan diri sendiri. Hal ini juga bisa terjadi pada anak yang akan dilahirkannya.

Hakim sebagai pelaksana kehakiman mempunyai kemerdekaan dan otoritas dalam menjalankan tugasnya, dalam menjalankan tugasnya hakim tidak dipengaruhi oleh suatu instansi manapun karena hakim hanya tunduk kepada hukum dan keadilan disamping itu juga, dalam membuat putusan hakim harus mempertimbangkan segala temuan yang ditemukandidalampersidangan dan semua temuan tersebut harus dipertimbangkan untuk selanjutnya dijadikan pertimbangan untuk menentukan hukum.

Tidak sedikit dari perkara yang diatur dalam undang-undang maka dari itu hakim harus berusaha menggali dan menemukan hukumnya dengan sebaikbaiknya dalam penemuan hukum yang belum diatur dalam undang-undang mulamula, hakim berusaha menggali fakta-fakta tentang perkara yang akan diputuskan itu melalu alat bukti yang ada selanjutnya hakim menganalisisnya hasil dari analisis tersebut digunakan oleh hakim untuk menentukan hukumnya dan diterapkan dalam perkara yang bersangkutan.

Dalam mengambil keputusan hakim harus mempertimbangkan antara undang-undang yang ada dengan fakta dalam persidangan. Dalam perkara dispensasi nikah peraturan yang mengatur batasan usia seseorang yang dibolehkan melakukan pernikahan. Pasal 7 Undang-Undang Nomor 1 Tahun 1974, menyebutkan bahwa bila seseorang (yang beragama Islam) belum mencapai usia minimum, dapat mengajukan dispensasi nikah kepada pengadilan agama. Aturan lain yang mengatur dispensasi nikah adalah pasal 15 Kompilasi Hukum Islam, yang maksudnya sama dengan UndangUndang Nomor 1 Tahun 1974, namun demikian aturan hukum tersebut tidak merinci alasannya.

Hakim Pengadilan Agama dalam menetapkan pemberian dispensasi nikah terhadap pemohon mempunyai beberapa pertimbangan-pertimbangan yang mana pertimbangan hakim tersebut berdasarkan bukti- bukti dan saksi-saksi. Berdasarkan pada analisis pertimbangan 
yang digunakan oleh hakim Pengadilan Agama dalam memberikan penetapan dispensasi nikah mempuyai beberapa pertimbangan, yaitu pertimbangan hakim yang berdasarkan pada peraturan yang ada yang mana dalam pertimbangan hakim dalam menjatuhkan penetapannya itu harus disesuaikan dengan hukum yang ada. Selain itu, dalam menetapkan izin dispensasi nikah yaitu dalam mengambil penetapan hakim mengali berdasarkan keterangan dari bukti- bukti dan keterangan dari saksi-saksi kemudian dari keterangan saksi-saksi tersebut dicocokkan dengan keterangan dari pemohon, saksi yang biasa dihadirkan oleh hakim dalam persidangan adalah dua orang.

Islam bersikap keras tak mengenal kompromi dalam memberantas kemaksiatan (penyakit masyarakat), karena apabila kemaksiatan itu dibiarkan merajalela berarti kita menjerumuskan kelembah kehinaan, sedangkan kemaksiatan itu ibarat kanker ganas yang apabila tidak segera diobati akan mengrogoti tubuh manusia sampai mati oleh karena itu pencegahan bersikap prioaktif dan preventif (pencegahan) dalam memerangi kemaksiatan tersebut, ${ }^{16}$ dalam menghilangkan kemadharatan itu tidak boleh sampai menimbulkan kemadharatan lain baik ringan apalagi lebih berat. Namun bila kemadharatan itu tidak dapat dihilangkan kecuali dengan menimbulkan kemadharatan yang lain maka haruslah memilih kemadharatan yang relatif lebih ringan dari yang telah terjadi. Menurut persepsi hakim, madharatnya adalah ditakutkan bila tidak dinikahkan akan menambah dosa dan terjadi perkawinan di bawah tangan yang akan mengacaukan proses-proses hukum yang akan terjadi berikutnya atau mengacaukan hak-hak hukum anak yang dilahirkannya menurut Undang-undang.

Dispensasi nikah yang diajukan di Pengadilan Agama setelah penulis teliti penyebabnya terbesar adalah hamil di luar nikah, dan dalam kehidupan masyarakat orang yang hamil sebelum nikah merupakan sebuah aib dan apalagi aib itu dilakukan oleh orang yang baru menginjak dewasa (kurang umur untuk menjalankan pernikahan menurut undang-undang pernikahan), sehingga seringkali pernikahan dijadikan jalan alternatif untuk menutupi aib tersebut. Penyelesaian masalah sosial yang akan terjadi yaitu menikahkan anak yang sudah hamil terlebih dahulu untuk menutupi malu.

Berdasarkan pada penelitian yang telah penulis lakukan di Pengadilan Agama, bahwa hakim mengabulkan permohonan dispensasi nikah dengan pertimbangan untuk kemaslahatan, karena jika tidak dikabulkan akan dikawatirkan terjadi pernikahan siri yang mengakibatkan kekacauan nasabanak, selain itu juga hakim dalam mengabulkan dispensasi nikah, hakim selalu mengabulkan permohonan dispensasi kawin karena hubungan di luar nikah, dengan pertimbangan perempuan yang hamil tanpa suami akan dihina dan dikucilkan oleh masyarakat. Ini bisa

16 Dudung Abdul Rohman, Mengembangkan Etika Berumah Tangga Menjadi Moralitas Bangsa Menuju Pandangan Al-qur'an, Nuasan Aulia, Bandung, 2006, hlm. 36. 
mengakibatkan perempuan tersebut tidak mau bergaul dan mementingkan diri sendiri.

Tugas hakim sebagai pihak penegak hukum, setiap penerapan hukum atau keputusan hukum yang dibuat oleh hakim hendaklah sejalan dengan tujuan hukum yang hendak dicapai oleh syari'at. Apabila penerapan suatu rumusan akan bertentangan hasilnya dengan kemaslahatan manusia, maka penerapan hukum tersebut harus ditangguhkan. Demi pencapaian kemaslahatan yang merupakan tujuan utama dari penerapan hukum-hukum, pengecualian secara sah perlu diberlakukan.

Kemudian orang tua salah satu calon mempelai mengajukan perkara permohonan dispensasi kawin di Pengadilan Agama supaya dapat menikahkan anak mereka, seperti yang tercantum dalam Undang-Undang Nomor 1 Tahun 1974, Pasal 7 ayat (2) yang menyebutkan:

"Dalam hal penyimpangan terhadap ayat (1) pasal ini dapat meminta dispensasi kepada Pengadilan atau Pejabat lain, yang ditunjuk oleh kedua orang tua pihak pria maupun pihak wanita".

Dalam amar penetapan, Majelis Hakim mengabulkan permohonan Pemohon yaitu memberikan Dispensasi Kawin kepada Pemohon untuk menikahkan anaknya. Dengan pertimbangan bahwa akan menimbulkan madharat yang lebih besar jika kedua calon mempelai tidak segera dinikahkan. Penetapan Majelis
Hakim tersebut sudah tepat, karena tidak menyimpang dari ketentuan UndangUndang Nomor 1 Tahun 1974 yang mana tidak membahas secara khusus tentang dispensasi kawin dan Kompilasi Hukum Islam yang secara tersirat tidak melarang menikahkan seseorang yang telah melakukan hubungan luar nikah, apalagi hingga mengakibatkan kehamilan. Hal ini terdapat dalam Pasal 53 yang berbunyi sebagai berikut:

“(1) Seorang wanita hamil di luar nikah, dapat dikawinkan dengan pria yang menghamilinya.

(2) Perkawinan dengan wanita hamil yang disebut pada ayat (1) dapat dilangsungkan tanpa menunggu lebih dahulu kelahiran anaknya.

(3) Dengan dilangsungkannya perkawinan pada saat wanita hamil, tidak diperlukan perkawinan ulang setelah anak yang dikandung lahir".

Sementara itu, dalam Al-qur'an surat an-Nur ayat 3, Allah SWT berfirman sebagai berikut: ${ }^{17}$

“Lelaki pezina tidak menikah, kecuali dengan perempuan pezina atau perempuan musyrik. Dan perempuan pezina tidak dinikahi, melainkan oleh lelaki pezina atau lelaki musyrik. Dan diharamkan yang demikian itu kepada semua mukmin".

Orang-orang yang berbuat serong tentulah tidak ingin menikahi wanitawanita yang saleh. Demikian pula perempuan yang berbuat serong tidaklah

17 Departemen Agama RI, Al-Qur'an dan Terjemahannya, Mekar, Surabaya, 2004, hlm. 488. 
ingin dinikahi oleh orang-orang yang saleh. Ini adalah suatu hukum yang umum. Tetapi hal ini tidak memberi pengertian bahwa pezina sama sekali tidak boleh menikahi perempuan saleh dan juga tidak berarti bahwa semua perempuan pezina tidak beleh dinikahi oleh seorang lelaki yang saleh. Firman Allah itu bukanlah memberi pengertian bahwa lelaki pezina tidak boleh menikahi selain perempuan pezina. Atau tidak sah perempuan untuk mencegah terjadinya orang-orang Islam yang jiwanya lemah, hatinya mudah tertarik menikahi perempuan-perempuan jalang dengan mengharapkan harta dan kesenangan hidup. Tegasnya, ayat itu bukan menunjukkan bahwa pernikahan antara lelaki pezina dan perempuan tak berzina tidak sah. Begitu pula sebaliknya, pernikahan antara pria tidak berzina dengan perempuan pezina. ${ }^{18}$ Para ulama berselisih faham tentang bolehkah seorang lelaki menikahi perempuan yang telah dizinai. Imam Ahmad, Ibnu Hazm, Ibnu Taimiyah dan Ibnu Qayyim berpendapat tidak halal perempuan dan laki-laki berzina kawin sebelum bertobat dan harus menunggu masa iddahnya selesai, sedangkan Hanafi dan Syafi'i membolehkan tanpa menunggu masa iddah. ${ }^{19}$

\section{PENUTUP}

Hakim dalam mengabulkan permohonan dispensasi nikah anak yang hamil di luar pernikahan didasarkan pada pertimbangan hukum, bahwa hakim ketika hakim menjatuhkan penetapannya harus sesuai dengan dalil-dalil dan bukti-bukti hukum yang diajukan dan pertimbangan keadilan masyarakat, bahwa menikahkan anak yang sudah hamil terlebih dahulu untuk menutup malu, di samping pertimbangan perempuan yang hamil tanpa suami akan dihina dan dikucilkan oleh masyarakat. Putusan hakim dalam memutuskan perkara permohonan dispensasi kawin karena hubungan luar nikah oleh Pengadilan Agama, dalam amar putusnya selalu memuculkan, bahwa dispensasi nikah diberikan untuk kemaslahatan dan kemudharatannya, ditakutkan bila tidak dinikahkan akan menambah dosa dan terjadi perkawinan di bawah tangan yang akan menimbulkan proses-proses hukum yang akan terjadi berikutnya atau mengakibatkan ketidakpastian secara yuridis formal.

\section{DAFTAR PUSTAKA}

Abdurrahman, Kompilasi Hukum Islam di Indonesia, Akademika Pressindo, Jakarta, 1995.

Asmin, Status Perkawinan Antar Agama Ditinjau dari Undang-Undang No. 1/1974, Dian Rakyat, Jakarta, 1986.

Departemen Agama RI, Al-Qur'an dan Terjemahannya, Mekar, Surabaya, 2004.

\footnotetext{
18 Teungku Muhammad Hasbi Ash-Shiddieqy, Tafsir Al-Qur'anul Majid An-Nur 4, Pustaka Rizki Putra, Semarang, 2000, hlm. 2788.

19 Sayyid Sabiq, Fiqh al-Sunnah Jilid 2, Dar al-Fikr, Beirut, 1992, hlm. 87-88.
} 
Direktoral Jenderal Pembinaan Kelembagaan Agama Islam, IImu Fiqihh Jilid II, Departemen Agama, Jakarta, 1985.

Djaya S. Meliala, Masalah Perkawinan Antar Agama dan Kepercayaan di Indonesia dalam Perspektif Hukum, Vrama Vidya Dharma, Bandung, 2006.

Dudung Abdul Rohman, Mengembangkan Etika Berumah Tangga Menjadi Moralitas Bangsa Menuju Pandangan Al-qur'an, Nuasan Aulia, Bandung, 2006.

Hilman Hadikusuman, Hukum Perkawinan Indonesia Menurut Perundangan, Hukum Adat dan Hukum Agama, Mandar Maju, Bandung, 1990.

Imam Abu Hamid Muhammad Ibn Muhammad al-Ghazali, Ihya 'Ulum adDin, Jilid 2, Dar al-Fikr, BeirutLibanon, 1989.

K. Wantjik Saleh, Hukum Perkawinan Indonesia, Ghalia Indonesia, Jakarta, 1976.

Kamal Muchtar, Asas-asas Hukum Islam tentang Perkawinan, Bulan Bintang, Jakarta, 1974.

Ridwan Syahrani, Seluk Beluk dan Asasasas Hukum Perdata, Alumni, Bandung, 2002.

Sayyid Sabiq, Fiqh al-Sunnah Jilid 2, Dar alFikr, Beirut, 1992.
Sutan Marajo Nasaruddin Latif, Problematika Seputar Keluarga dan Rumah Tangga, Pustaka Hiddayah, Bandung, 2001.

Teungku Muhammad Hasbi Ash-Shiddieqy, Tafsir Al-Qur'anul Majid An-Nur 4, Pustaka Rizki Putra, Semarang, 2000. 